\title{
An assessment of deep hot-water drilling as a means to undertake direct measurement and sampling of Antarctic subglacial lakes: experience and lessons learned from the Lake Ellsworth field season $2012 / 13$
}

\author{
Martin J. SIEGERT, ${ }^{1}$ Keith MAKINSON, ${ }^{2}$ David BLAKE, ${ }^{2}$ Matt MOWLEM, ${ }^{3}$ Neil ROSS ${ }^{4}$ \\ ${ }^{1}$ Grantham Institute, and Department of Earth Science and Engineering, Imperial College London, London, UK \\ E-mailm.siegert@imperial.ac.uk \\ ${ }^{2}$ British Antarctic Survey, Natural Environment Research Council, Cambridge, UK \\ ${ }^{3}$ National Oceanography Centre, University of Southampton, Southampton, UK \\ ${ }^{4}$ School of Geography, Politics and Sociology, Newcastle University, Newcastle upon Tyne, UK
}

\begin{abstract}
In the early hours of 25 December 2012, an attempt to explore Subglacial Lake Ellsworth, West Antarctica, using a specially designed hot-water drill, was halted. This UK project, involving several universities, the British Antarctic Survey and the National Oceanography Centre, had been in planning for 10 years. The project developed a full blueprint for subglacial lakes research, involving access to the subglacial environment through deep drilling, direct measurement and sampling of water and sediment by the construction of a probe and sediment corer, and environmental protocols to ensure cleanliness in line with international agreements on stewardship and protection of subglacial systems. Drilling was ceased after the main borehole failed to link with a subsurface cavity of water, built up over $\sim 40$ hours. Without this link, insufficient water was available to continue drilling downwards to the lake, $\sim 3000 \mathrm{~m}$ beneath the surface. On return to the UK, an external review of the programme was undertaken to formally assess the reasons for the fieldwork failure, and to make recommendations on the modifications necessary for success. From this review, the Lake Ellsworth programme formulated a pathway along which a second attempt to explore the lake can be developed. Here details of the Lake Ellsworth field experiment, the circumstances that led to its failure and the corrections required are presented. Hot-water drilling is still regarded as the only feasible scheme for assuring clean access to the subglacial environment. The lessons learned from the Lake Ellsworth experience are substantial, however, and demonstrate that considerable technological and methodological advances are necessary for successful future research on subglacial lakes beneath thick $(>2 \mathrm{~km})$ ice.
\end{abstract}

KEYWORDS: glaciological instruments and methods, radio-echo sounding, subglacial exploration geophysics, subglacial lakes

\section{BACKGROUND AND INTRODUCTION}

Although subglacial lakes were first discovered $>40$ years ago as a consequence of the measurement of the ice-sheet bed by long-range airborne radio-echo sounding (RES) (Robin, 1969; Oswald and Robin, 1973; Robin and others, 1977), it was not until the measurement of Lake Vostok's (Antarctica) dimensions (Ridley and others, 1993; Kapitsa and others, 1996) that broad scientific interest in them was established. The specific information that led to this change concerned the identification through seismic sounding of Lake Vostok's water depth at $>500 \mathrm{~m}$ (Kapitsa and others, 1996), making it one of the world's top ten largest lakes. Accompanying the publication of this finding were two evaluations of its potential significance. First, Bentley (1996) showed the physical processes controlling how the lake may have formed, by melting at the ice base and accumulation of water within basal topography, which though applied to Lake Vostok could be generalized over much of the icesheet base. Second, Ellis-Evans and Wynn-Williams (1996) hypothesized that the lake could be a viable habitat for life, and speculated about the forms and concentrations of microorganisms that might exist there. In the same year, a new inventory of subglacial lakes, as recorded by RES, was compiled (Siegert and others, 1996), revealing stored water at the bed of much of the Antarctic ice sheet. In combination, these papers led to a sudden appreciation that the Antarctic ice-sheet base likely contains a significant, diverse and isolated habitat for microorganisms. To develop this scientific interest, four international workshops were held in the 1990s (Cambridge, UK 1994; St Petersburg, Russia 1998; Washington DC, USA 1998; and Cambridge, UK 1999). At these meetings, the notion of sediments at the floors of subglacial lakes as potential recorders of past icesheet and climate change was discussed (P. Barrett, unpublished information). Thus, by the end of the 1990s, two scientific hypotheses regarding life in subglacial lakes and climate records in lake-floor sediments had emerged. As these hypotheses are testable by direct measurement and sampling of subglacial lakes, attention turned to how and when these environments could be accessed.

By the turn of the century, although there was international agreement that direct measurement and sampling of subglacial lakes was warranted to test the two scientific hypotheses, little consensus existed on how and where such work should take place. Convergence of views among the scientific community was assisted by a number of events and 
reports, which greatly assisted the development and planning of subsequent subglacial lake exploration programmes. The timeline of these activities is as follows. In 2000, the Scientific Committee on Antarctic Research (SCAR) convened a group of specialists named SALE (Subglacial Antarctic Lake Environments) as a forum for scientists and technologists to discuss how subglacial lake exploration might take place. In 2004, this committee transformed into one of SCAR's scientific research programmes. By 2005, a new inventory revealed evidence for 145 Antarctic subglacial lakes, spread across the continent (Siegert and others, 2005). This was followed by evidence from satellite altimetry demonstrating hydrological connections between subglacial lakes (Wingham and others, 2006; Fricker and others, 2007), leading to an appreciation that subglacial hydrology was far more dynamic in Antarctica than had been generally appreciated previously. In 2006, in advance of the International Polar Year, SCAR SALE convened a workshop in Grenoble, France, to further advance international agreement on scientific plans and technology. A year later, as part of an independent assessment of subglacial lakes research, the US National Academies published a review on these plans from an environmental and conservation perspective (NRC, 2007). This review was debated, in the light of emerging scientific proposals to undertake subglacial lake access, at an international meeting in Baltimore, USA (Siegert and others, 2011). From these advances, debates and reviews, SCAR built a code of conduct on subglacial lake exploration, which was agreed by the Antarctic Treaty Consultative Meeting (ATCM; in Buenos Aires, Argentina, in 2011), providing guiding principles on how direct measurement and sampling of subglacial lake systems should be undertaken in a manner that would preserve them, and their surroundings, as pristine environments.

Planning to undertake direct measurement and sampling of Subglacial Lake Ellsworth began in 2002, through a series of UK-wide meetings that progressed thinking on the technology required and the science that might be achieved. These plans were informed by the international debates taking place at the same time (primarily via SCAR), and indeed fed back into the broader debates on subglacial aquatic environments. The first issue considered concerned the subglacial lake best suited for exploration. Siegert (2002) analysed individual details of the 77 subglacial lakes known at the time (Siegert and others, 1996), in order to determine which were the most suitable for exploration in the first instance. The result was a set of criteria that SCAR SALE employed to develop an international plan for subglacial lake exploration (Priscu and others, 2003). Based on these criteria, Siegert (2002) concluded that relatively small subglacial lakes in West Antarctica would likely be most appropriate. As the inventory of lakes increased to 145 (Siegert and others, 2005), Siegert and others (2004) showed how one lake, Subglacial Lake Ellsworth, matched the criteria well. Based on a single airborne geophysical transect (Drewry and Meldrum, 1978), which defined the lake by flat, bright radio-echo sounding reflections, they showed that the lake was $\sim 10 \mathrm{~km}$ in length, $\sim 3 \mathrm{~km}$ beneath the ice and, judging by the side-wall slopes at the edge of the lake, was likely to be more than $10 \mathrm{~m}$ deep, possibly much deeper. While this information gave confidence in Lake Ellsworth being a good target for exploration, it was insufficient to build a proposal for exploration, given that the precise dimensions of the lake, including its depth and topographic setting, were not known. To solve this, a dedicated geophysical survey of the lake was conducted in 2007/08 and 2008/09, involving ground-based RES to determine the outline of the lake, the nature of the surrounding topography and information about the inputs and outputs of water to the lake, and seismic sounding to measure the water depth and evidence for sub-lake sediments. The survey was very successful, and resulted in an unprecedented resolution of data over a subglacial lake system (Woodward and others, 2010).

Lake Ellsworth is located within an overdeepened section of a subglacial topographic valley, within the Ellsworth Subglacial Highlands (Siegert and others, 2012), and $\sim 20 \mathrm{~km}$ from the ice divide (Fig. 1). Based on known geomorphological processes, it is likely the trough formation pre-dates the current ice sheet (Ross and others, 2014), most likely being incised by an outlet glacier flowing from a small, dynamic ice cap centred over the highlands, possibly in a fjord-like setting when much of present-day West Antarctica was covered by the sea. The lake is $14.7 \mathrm{~km}$ long, with an area of $\sim 28.9 \mathrm{~km}^{2}$, and exists beneath 3280$2930 \mathrm{~m}$ of ice (Woodward and others, 2010). Narrow (generally $<1.5 \mathrm{~km}$ ) in its up-ice third, the lake broadens $(>3.05 \mathrm{~km})$, before narrowing into a small embayment in its lowermost $2.5 \mathrm{~km}$. The down-ice limit of the topographic overdeepening is marked by a $6 \mathrm{~km}$-long ridge with a $\sim 200 \mathrm{~m}$ relief, which crosses the entire width of the trough. This ridge is above the elevation of the adjoining lake, and likely plays a key role in controlling the lake drainage. Lake Ellsworth can therefore be considered as a 'topographically controlled' subglacial lake, making it potentially insensitive to glacial-interglacial ice-sheet changes (Ross and others, 2011a). The depth and bathymetry of Lake Ellsworth was established from seismic reflection data (Woodward and others, 2010), revealing it to have a water volume of $\sim 1.4 \mathrm{~km}^{3}$ (Woodward and others, 2010) and a maximum lake depth of $156 \mathrm{~m}$. Analysis of the seismic data indicates the lake bed is composed of high-porosity, low-density sediments, similar to material found on the deep ocean floor, and indicative of deposition in a low-energy environment (Ross and others 2011a; Siegert and others, 2012). The sediment is at least $2 \mathrm{~m}$ thick, and there is no evidence for consolidation by overriding ice. This latter finding adds confidence that the lake is an ancient stable system as, conceptually, it would likely take several hundred thousand years to accumulate $>2 \mathrm{~m}$ of sediment (Bentley and others, 2011), and, in the absence of the lake, for the ice sheet to over-compact the sediments.

First results on the lake's water depth were issued from the field at the start of 2008. In the previous 4 years, the technological and cleanliness requirements for lake access, measurement and sampling had been defined. Importantly, a precise location for lake access was determined, being a location which best optimized the programme's scientific potential (Woodward and others, 2010). Consequently, the exploration of Lake Ellsworth was able to be formally proposed in early 2008, with funding granted by the UK Natural Environment Research Council (NERC) in December that year. As plans took shape, a comprehensive environmental evaluation (CEE) of the programme was submitted to the Committee on Environmental Protection (part of the Antarctic Treaty Consultative Meeting) in Buenos Aires in June 2011, which was subsequently modified in light of comments received and submitted to the same committee a 
year later. Following a supportive response from the ATCM in Hobart in 2012, the UK Foreign and Commonwealth Office issued the British Antarctic Survey (BAS) with a permit to conduct the fieldwork in the early summer of 2012. Details of the Lake Ellsworth experiment, including the environmental considerations and mitigation strategies, are summarized briefly below and are available in Siegert and others (2012).

The aim of this paper is to explain the reasons why the fieldwork failed to achieve its target of lake entry, and to present how the problems encountered can be rectified for future research at Lake Ellsworth and, indeed, in other deep $(>2 \mathrm{~km})$ subglacial environments. We now know of $>350$ Antarctic subglacial lakes (Wright and Siegert, 2012). While several of these would make compelling targets under the criteria established by Siegert (2002), the knowledge of Lake Ellsworth's dimensions, and topographic and glaciological settings, which is essential to configuring plans for its direct measurement and sampling, continue to make it an outstanding candidate for exploration.

\section{EXPERIMENT DESIGN}

The programme's plan was to access the lake using a bespoke deep hot-water drill to melt a clean hole from the ice surface to the lake, through which a clean probe would be deployed to take measurements and samples of the water, followed by a clean percussion corer to acquire lake-floor sediments (Siegert and others, 2012). Cleanliness protocols needed to be developed, to ensure a negligible level of contamination (i.e. well below our ability to measure it) to the lake during the experiment, as did assurance on the issue of potential gas exchange between the lake and ice surface upon lake entry (Brito and others, 2013).

The hot-water drill design was centred on a single 1.5 MW boiler, which fed hot water into two hoses (Fig. 2). First, a $340 \mathrm{~m}$ umbilical hose was used to create a hole $300 \mathrm{~m}$ deep, at which point a reservoir of water was created. As the top $\sim 70 \mathrm{~m}$ of the ice sheet is permeable, drilling through this layer required substantial water storage at the ice-sheet surface. This water was created by melting snow into three $30000 \mathrm{~L}$ tanks, using power from the boiler via a discrete circulation system. Once below $70 \mathrm{~m}$, the pump on the umbilical could be activated, to pass water back to the surface and avoid further loss of water to the ice sheet. Upon creation of the subsurface reservoir, a second (main) hole was created through a $3400 \mathrm{~m}$ single length of hose. Using water held within both the surface tanks and subsurface reservoir, initial water loss in the upper $70 \mathrm{~m}$ was not anticipated as a major problem. The main hole needed to link into the subsurface cavity before further drilling to the lake. This was necessary to recirculate water to the surface and to regulate the water level of the main borehole prior to lake entry; a hydrological head $\sim 284 \mathrm{~m}$ below the ice surface was required to equilibrate the borehole and lake water pressures, to ensure minimal exchange between the two upon the moment of access.

Cleanliness was assured by the following series of measures. First, all the water used to drill the holes was passed through a $0.1 \mu \mathrm{m}$ filter to remove particles and radiated with strong ultraviolet (UV) light $(254 \mathrm{~nm}, 200 \mathrm{~W}$ ) to kill any remaining microorganisms. Second, all the hoses were wiped with ethanol prior to their descent in the ice sheet. Third, the main hole was airlocked, and the upper
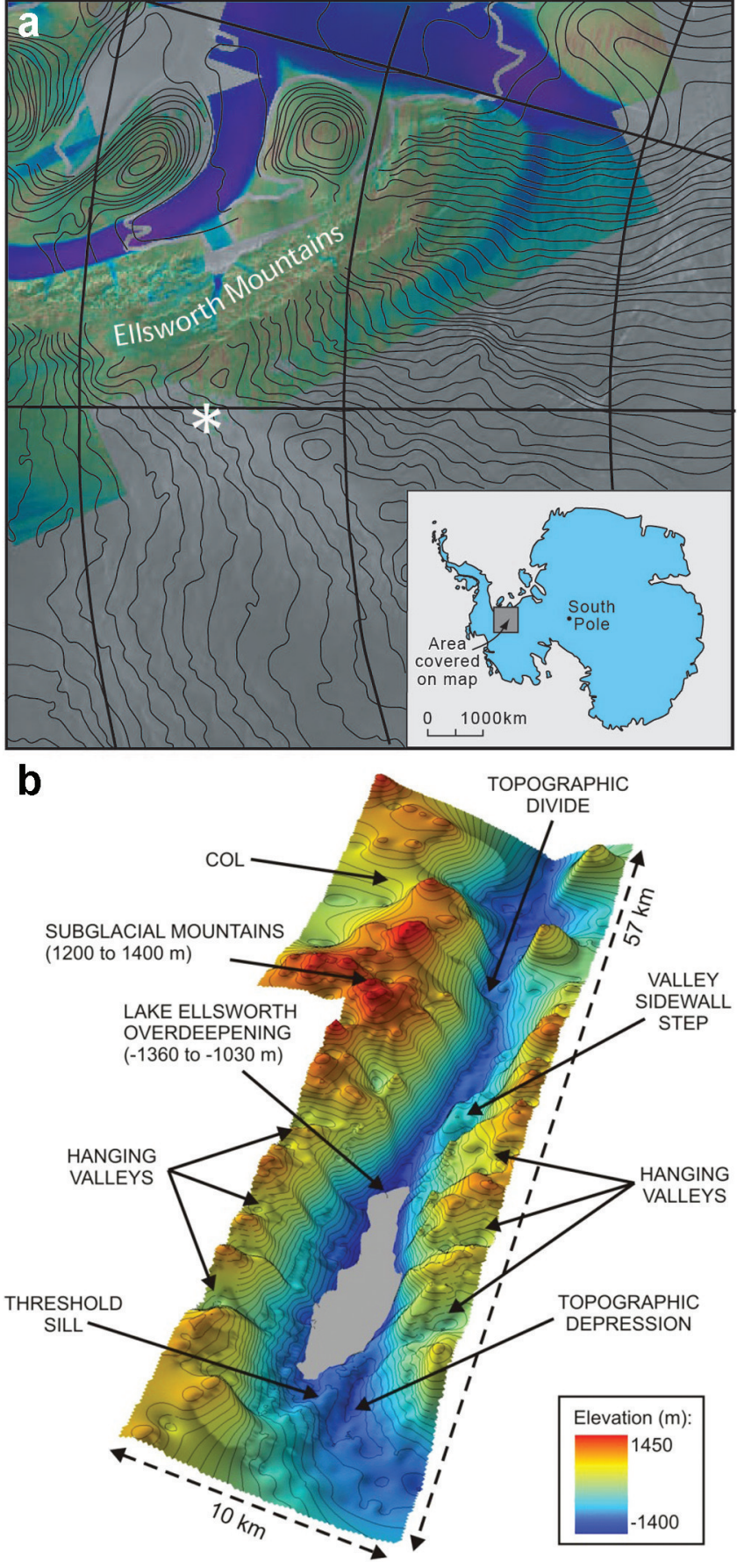

Fig. 1. (a) The location of Lake Ellsworth (shown as an asterisk) superimposed against an interferometric synthetic aperture radar (InSAR) surface ice velocity map of the region (green represents lower velocities, purple corresponds to higher velocities) and the ice surface elevation (contours are in $50 \mathrm{~m}$ intervals). Adapted from Siegert and others (2004). (b) Three-dimensional view of the surface extent of Subglacial Lake Ellsworth, and its surrounding topography. Numerous glacial geological features are noted, which collectively demonstrate that the landscape in this region has been heavily influenced by the erosive action of dynamic upland glaciation predating the slow-flowing existing ice cover. Ice flow is approximately along the axis of the trough (Ross and others, 2011b). Adapted from Ross and others (2011a) and Siegert and others (2012).

air-filled component was radiated by UV light through a specially designed probe. Fourth, all the probes and corers were built in ultra-sterile conditions, and transported to the ice sheet in robust bags. Fifth, a deployment system was 


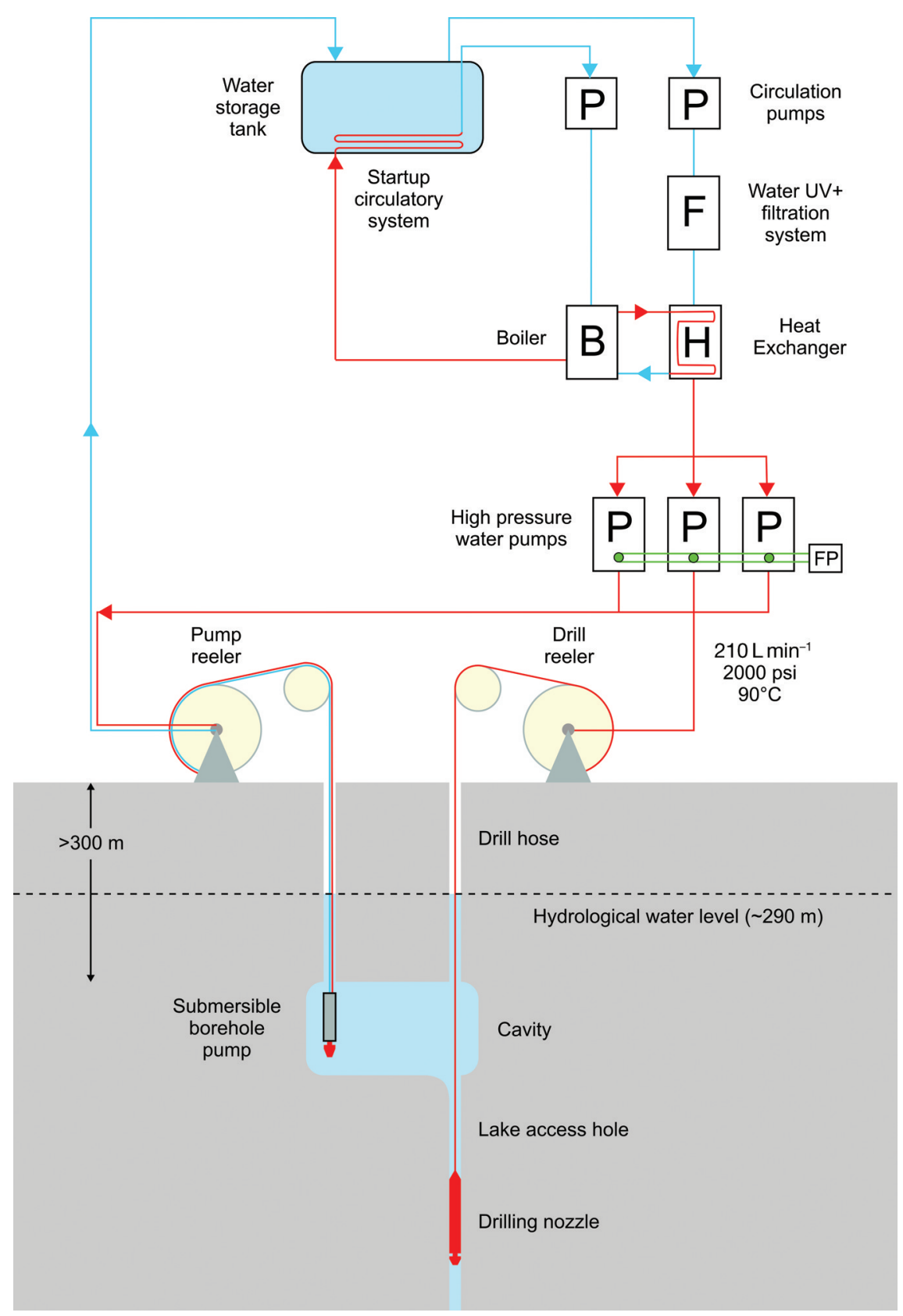

Fig. 2. Schematic diagram showing the set-up of the Lake Ellsworth hot-water drill system. $H=$ heaters; $P=$ pumps; $F=$ filters. From Brito and others (2012b).

configured, using a series of airlocks formed from glove hatches and seals, cleaned with hydrogen peroxide vapour, to ensure the probes could be placed within the clean hole, and extracted from it, without exposure to the atmosphere.

The drilling procedure was calculated to allow the main hole to be $36 \mathrm{~cm}$ wide upon deployment of the probe. This procedure required the rate of drill descent and the water temperature to be controlled to match the calculated profile. To ensure this, measurements of water temperature, winch load and drill descent rate were configured to be available to the drilling engineer.

It is interesting to note similarities and differences between the configuration of the Lake Ellsworth experiment and that of two other Antarctic subglacial lake programmes. The first is a Russian experiment to access Subglacial Lake Vostok, a $>500$ m deep lake beneath $\sim 3750 \mathrm{~m}$ of ice in East Antarctica (Lukin and Bulat, 2011). While this programme has implemented a comprehensive environmental evaluation for discussion at the ATCM, its preferred use of the Vostok ice-core hole, positioned over the southern extreme of the lake, has been controversial. This is because the hole is filled with kerosene drilling fluid, making assurances on cleanliness and sterility challenging. Nonetheless, in early February 2012 Russian ice corers successfully accessed the lake, after drilling fluid was observed overtopping the core hole (i.e. water from the lake pushed into the core hole upon entry of the drill). Russian colleagues are currently examining water samples collected through this activity, and plans are being devised to use the access hole to deploy equipment into the lake, in order to take direct measurement and samples. The second is a US-led programme, to explore Subglacial Lake Whillans, Siple Coast, West Antarctica (Fricker and others, 2011). A similar drilling procedure to that configured for Lake Ellsworth was successfully used to 
penetrate and sample the lake in January 2013. As the lake is shallow $(<2 \mathrm{~m}$ at the drill site, beneath $\sim 800 \mathrm{~m}$ of ice) and probably ephemeral (Fricker and others, 2007), a comprehensive environmental evaluation was not considered necessary, reducing the requirement to undertake the work in ultra-sterile conditions.

\section{FIELDWORK DIARY FOR DECEMBER 2012}

The hot-water drilling system was configured and its function tested in Cambridge between 2009 and 2011. It was designed to fit within a series of $20 \times$ ISO (International Standards Organization) shipping containers, to allow portability and ease of use within the field. In November 2011, some of the heavy items (boiler, hoses and winch containers) were transported to the Lake Ellsworth location and stored for overwintering. In November of the following year, the lake probes and scientific equipment were delivered to the site with eight engineers and technicians from BAS and the National Oceanography Centre (NOC), who began assembling the equipment, ready for commencement of the experiment in December 2012. On 1 December, four scientists joined the team at Lake Ellsworth, including principal investigator (PI) Martin Siegert, to provide general assistance to the experiment (i.e. manual labour such as snow shovelling) and to take control on scientific matters related to the probe deployments and sample retrieval.

The following text is taken from an abridged version of the PI's field diary, which records the events and issues faced by the field team between 1 and 25 December 2012 . Though it is an abbreviated and subjective record, it was used to describe the fieldwork by Lake Ellsworth's formal self-evaluation to the NERC Failure Review Board, as discussed in Section 4.

\section{December}

Martin Siegert, Martyn Tranter, Dominic Hodgson and David Pearce (programme scientists) arrive on site. Rest of the SLE [Subglacial Lake Ellsworth] team (Chris Hill - programme manager and expedition leader; Andy Tait \& Andy Webb drilling engineers; and Ed Waugh \& Robin Brown - NOC probe/instrument deployment engineers; Riet van de Velde - Camp Manager; Scott Iremonger - plant mechanic; Pete Bucktrout - BAS Cameraman) have been working for the last three weeks. The field site is set up [as illustrated in Figs 3 and 4] and checks and tests are about to begin.

\section{December}

Digging the well head of the main borehole. An auger used to drill to $4-5 \mathrm{~m}$, and the main well head is installed and linked to the deployment containers' rails.

\section{December}

Drill system: Minor problem reported; load cells not working, otherwise OK. [Down-hole] Instruments: All OK bar the downward looking camera on the percussion corer.

\section{4-5 December}

Testing the probe deployment system [Fig. 5a].

\section{December}

Bad news. Boiler Control Panel fails upon switch on. No idea why this happened. But the container was not at the boiler operating temperature when switch on occurred. This is our best explanation for the failure. Replacement board used, not activated. Spare board ordered from the suppliers, will take $\sim 10$ days to arrive.

\section{December}

More boiler issues. Various valves cracked, and pressurisation system not working properly due to faulty gauges. It appears the boiler had not liked the winter, and was probably not properly conditioned to face the winter. 'Work arounds' found for these ailments, but not ideal.

\section{December}

Drill system OK: load cells still not working though. Probe deployment testing going well. Day and night shifts being organised.

\section{December}

Saturday. Using the weekend to get some rest ahead of drilling on Monday, and to adjust to night shifts. Final preparations around the drill site.

\section{December}

Final briefing before tomorrow's drilling. Run through health and safety and first aid \& medical procedures. Spill kit awareness is discussed and noted. Everyone in the camp must now carry a radio for comms.

\section{0-11 December}

Boiler switch on process. Boiler being filled. Lots of shovelling snow into the onion tanks. More minor problems with the pressurisation pumps, this time frozen again. Boiler being warmed for 24 hours.

Boiler turned on $\sim 080011$ December; this time control board responds well. Some queries over an error message, resolved after satellite phone call with the manufacturer.

Boiler activated $\sim 090011$ December.

\section{1-12 December}

Shovelling snow into onion tanks; $2 \times 30000$ litres.

0700 12th. Boiler is very smoky; Andy Tait to phone manufacturer for solution. Probably to do with altitude difference compared with Cambridge, where it was commissioned.

1700 12th. Boiler now working well. Second tank now full. Ready for drilling the cavity hole.

\section{December}

0030. Boiler seems to be running hot, and apparently burning material on its exterior.

0550. Umbilical hose connected to the second well head. 0730. Cat pumps and filters being primed.

1650. Umbilical drilled for $60 \mathrm{~m}$, but was losing too much water so was halted. Drill nozzle was bent in the process [Fig. 4b]. Various minor ailments with the boiler required phone calls with suppliers. The onion tanks need to be refilled with water, but no immediate rush.

\section{December}

0040. Snow shovelling. Ed Waugh calculating the loss of water in onion tanks due to evaporation; loss of water at $2-3 \mathrm{~cm}$ per day in agreement with this idea, so no major leaks in the tanks.

2215. Various boiler issues have been resolved, or 'worked around'. 


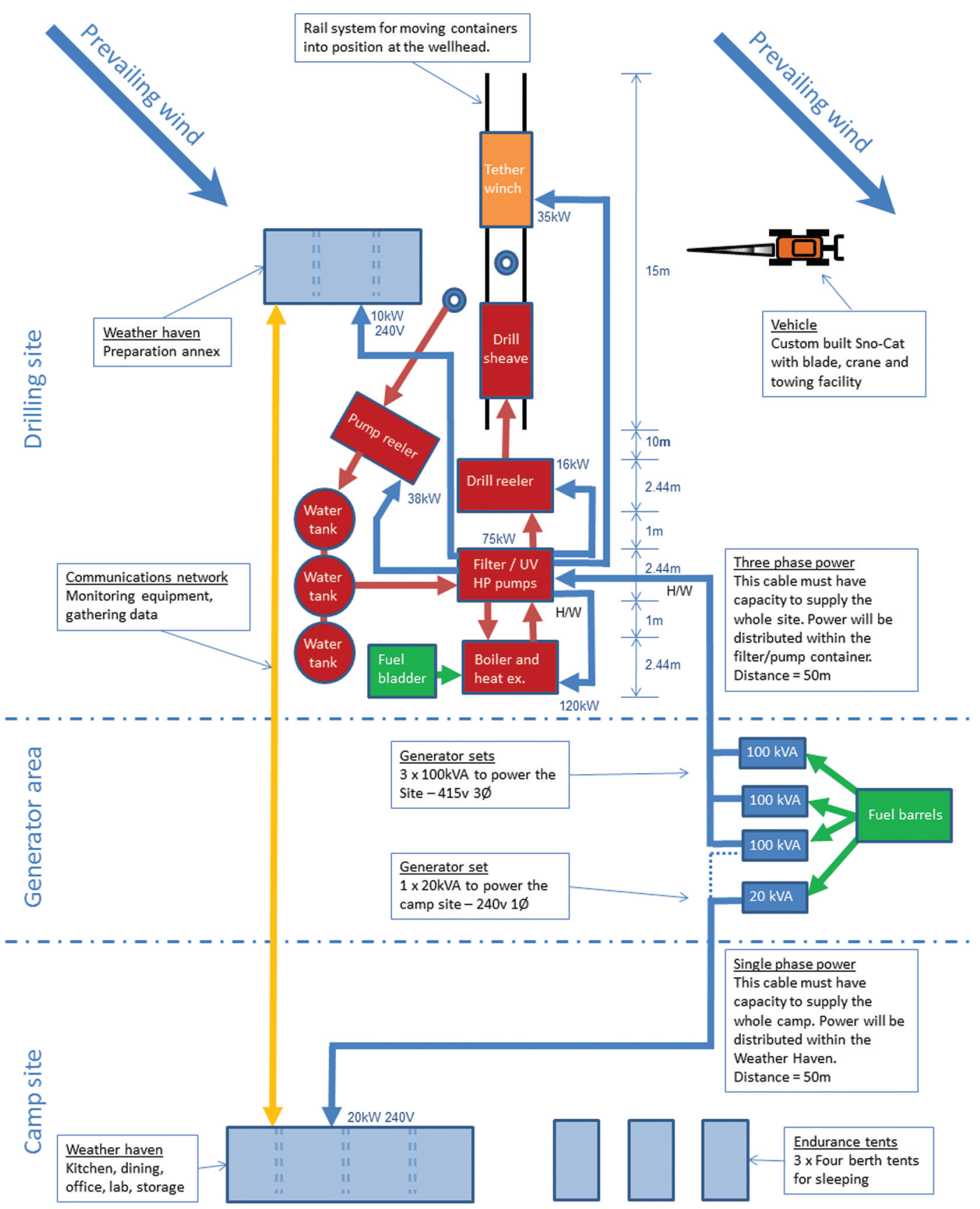

Fig. 3. Schematic layout of the field camp. Taken from Siegert and others (2012).

2240. However, pressurisation sensors broken, as are the seals on the pressure pumps.

\section{December}

0215. Working all night to extract the pumps to examine.

0520. After 3 hours of examination, the pumps simply needed tightening, due to ice expansion. We're confident of the fix, as we did a thorough strip down and test.

1035. Steps backwards. The pressure sensors on the boiler don't work, and so we're tricking the system to start up.

1045. Smoke from the boiler stack; good news that it's running again, albeit smokey. Planning to commence drilling after lunch.

1600. Very bad news. The second control board has failed, this time more catastrophically than before [Fig. 4c].

Discussions on whether we can cannibalise from the two boards. No is the answer.
Even if the replacement board came, it may fail too. Everyone rather saddened and depressed by this situation.

Thoughts on failure. The component that failed was a varistor; a variable resistor. This is supposed to protect the system from spikes on the power feed. Thought 1 . Winterisation. The board may not have liked the cold winter temps. Thought 2. Power surge; thought possible but would mean our generators are not behaving as we would wish. Thought 3 . Faulty component. At this point the programme looks off.

\section{December}

0440. Agreed to wait for 3rd control board to arrive.

0900. Andy Tait phoning the burner manufacturer. Importantly the failure took place at the start of drilling, and so we have enough fuel for a restart. Decided to keep ticking things over, although this will cost fuel. The boiler manufacturer will need to instruct us on how to programme the control board. 


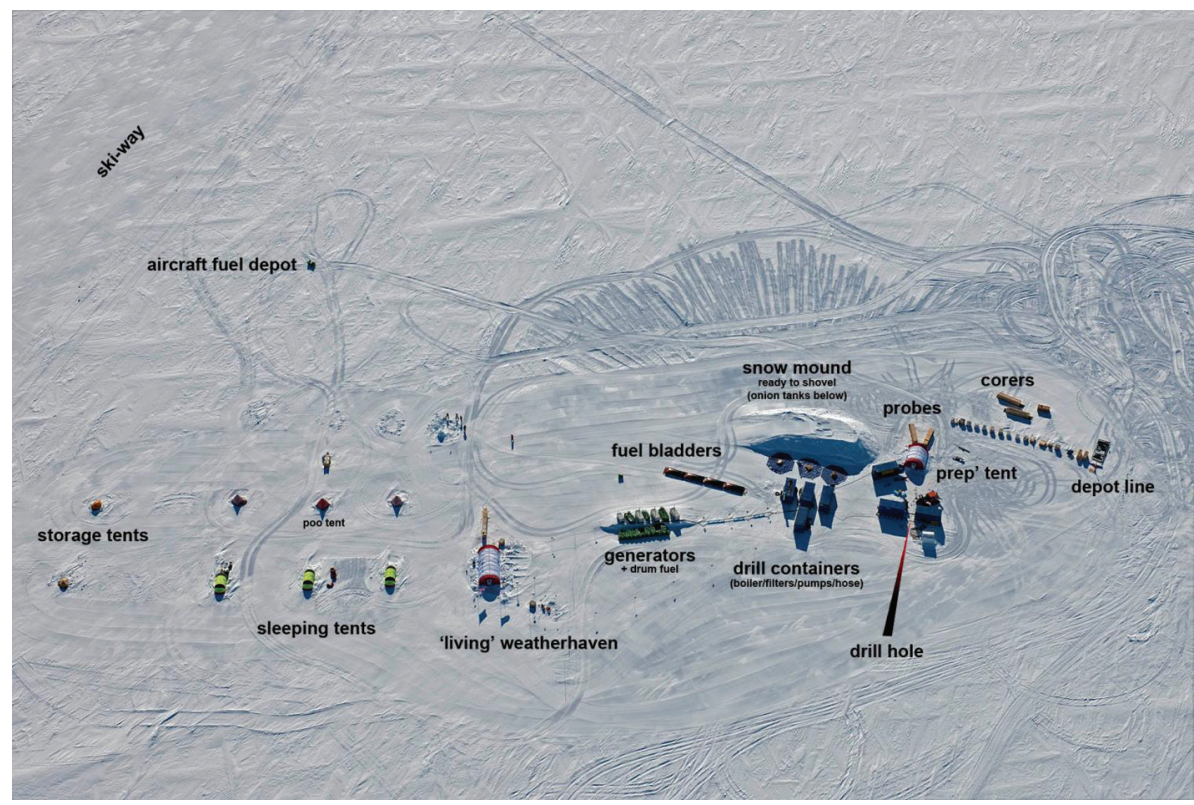

Fig. 4. Aerial photograph of the Lake Ellsworth field camp. Taken on 1 December 2012. Courtesy of Peter Bucktrout, NERC British Antarctic Survey.

1830. Winch load cells still not working; Ed Waugh to take a look at. Fuel still available for a full deployment, but now too low to have a full second deployment. Replacement control board now at Santiago: could have it on site on 20th.

\section{December}

1715. After lengthy calls, we found out the two failed control boards had faulty varistors, which had apparently failed on other burner control units. The replacement is from a new batch. While this makes faulty component the most likely explanation it doesn't rule out the power spike issue, so we are being careful with the generators and power use.

\section{8-20 December}

Things ticking over waiting for the new board; needing to keep 60000 litres of water warm is costing fuel. Topping up onion tanks with snow to maintain their levels (loss due to evaporation according to Ed Waugh's calculations on 14 December).

1645 20th. Illyushin flight to ALE [Antarctic Logistics and Expeditions] and Twin Otter flight to SLE with new control board.

\section{December}

Fitting the new control board onto the burner.

1150. Efforts to restart the boiler are difficult. LCD screen also failed previously. Replaced with original screen (from first failed burner unit). All programming deleted; needs manual loading via satellite link with suppliers in the UK (Fig. 5d).

1840. Boiler on and working OK. Care being taken on loading/unloading the electricity use, as we still don't know that large electricity spike wasn't responsible for previous board failure.

\section{December}

1735. Drilling recommences. Boiler working well. But not at full power yet, due to temperature requirement of the umbilical (pump works $<40^{\circ} \mathrm{C}$ ). Bent nozzle on the umbilical again. Removed and restarted.
2200. $300 \mathrm{~m}$ reached; drilling paused and cavity starts to be built.

\section{December}

Main hose is connected to the well head. Main drilling commences at 1620 .

1945. Suddenly, everything stops. Generator has short circuited, and caused shut down in all the others. All is eerily quiet. One of the generators has failed and cannot be restarted. We can run on 2 generators, but this is a stretch (90\% of their capacity now needed $100 \%$ of time). We have no choice, however.

2200. The short circuit blew the control board on the boiler for third time. This time, however, the varistor did its job and routed the spike to the fuse, which blew. Fuse replaced and boiler on again.

2200. Drilling restarts.

\section{December}

Drilling continues but is slow progress.

0400. $7 \mathrm{~m}$ above the level of the cavity. Pausing.

0600. We believe the umbilical and main boreholes may be linked, as water loss from main borehole is matched by water pumped from cavity.

0750. The boiler cannot get to the required temperature of $90^{\circ} \mathrm{C}$. It stalls at $70^{\circ} \mathrm{C}$, which means we cannot get to the lake surface as it stands, according to Keith Makinson's new calculation emailed from Cambridge.

0825. Calls to the boiler suppliers again, to see if settings can be changed.

1540. Good news. Boiler is running up to temperature and is good to go.

90000 litres of water, 3 full onion tanks, on surface available now for use.

1540. Bad news. The main hole re-reamed and major water loss was observed. Our supposed borehole connection was misread. More (frantic) shovelling to replenish water loss. Now continue searching for cavity.

1800. Still no cavity connection, everyone exhausted but continuing to shovel. Umbilical is stuck in the ice. It is either 

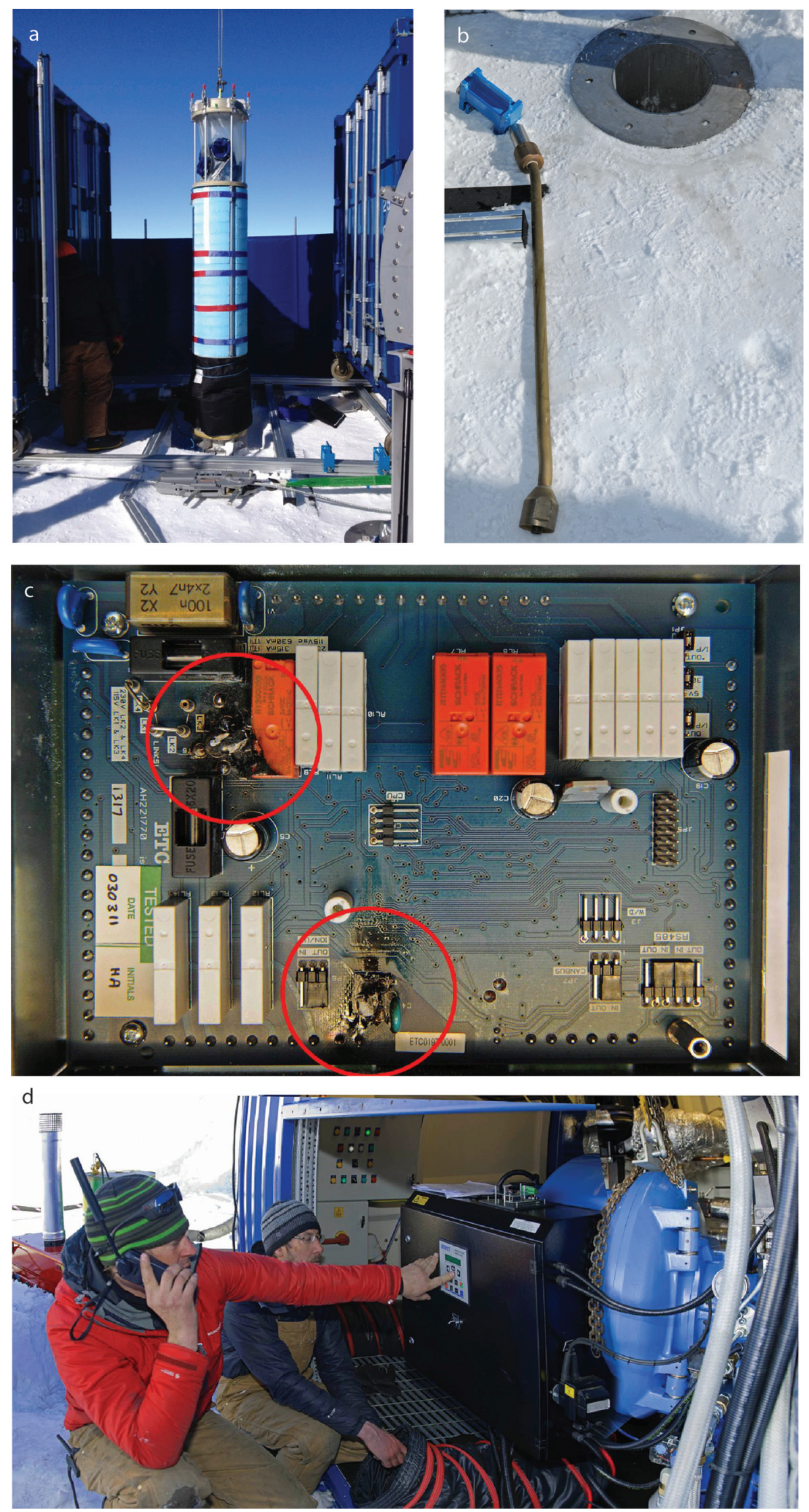

Fig. 5. (a) Probe deployment system being tested above the well head. In this photograph, the probe (in this case a UV probe, designed to sterilize the upper portion of the dry borehole) is connected to the well head by a glove box, which is wrapped in a thermal blanket and is being cleaned by exposure to hydrogen peroxide vapour. Once cleaned, the probe could be transferred to the borehole via the lower and upper glove-box compartments (for details of this procedure see Siegert and others, 2012). Photograph taken by M. Siegert. (b) Photograph of the drill nozzle extension that was bent while drilling the first borehole via the umbilical hose. Photograph taken by M. Siegert. (c) Hot-water drill boiler circuit board revealing two catastrophic component failures (circled in red). Courtesy of Peter Bucktrout, NERC British Antarctic Survey. (d) Drill engineers Andy Webb and Andy Tait programming the replacement boiler control board via satellite phone link to the manufacturer in the UK (on 24 December 2012). Courtesy of Peter Bucktrout, NERC British Antarctic Survey. 
jammed or frozen in. Likeliest explanation is that water wicked down the pipe from the overflowing main hose. This would explain why initially the water loss was negligible, but severe afterwards. Water can be seen at $40 \mathrm{~m}$ from the surface, so pooling over the frozen section.

\section{December}

0030. Drilling is ceased. Even if we did link the cavity and release the umbilical, the delays have meant we no longer have enough fuel to continue to the lake surface (at least 73 hours of drilling needed if cavity is connected now). In addition we are exhausted with shovelling. The decision was difficult to make but easy enough to call. Hot water being poured into umbilical to release it.

0450. Packing up has started already. Attempts to lift the umbilical with 3 tonnes of force failed. It is stuck.

1200. We are forced to cut the umbilical. A very bad day. Everyone resigned to events. Now discussing how the main drill failed to connect to the cavity.

\section{PROGRAMME FAILURE REVIEW BOARD}

Following cessation of fieldwork, the scientific team were uplifted from Lake Ellsworth, back to Rothera station between 27 and 30 December, and to the UK early in the new year. The engineers and technicians remained at Lake Ellsworth to pack up the equipment, ready for its transport back to Union Glacier. The boiler, probes and scientific equipment were transferred from Union Glacier to Punta Arenas, Chile, from where they were shipped back to the UK (by May 2013). The winches, pumps and other containers were held at Union Glacier ready for transfer back to the UK in the following season.

Once back in the UK, attention among the programme's scientific leaders focused on understanding why the Lake Ellsworth experiment was unsuccessful, and drawing initial plans for a second attempt. A first meeting was held on 10 January at NERC headquarters to discuss the issues encountered and to agree a time frame over which plans might be produced. A formal Failure Review Board (FRB) was convened by NERC, to independently assess the technical issues that caused the experiment to be halted, and to make recommendations on their mitigation. A series of reports were submitted to this review by the Lake Ellsworth team on 29 March, including a drill report and an overarching programme report, each providing technical suggestions relating to how the programme could be restarted. The review itself was convened between 13 and 14 May in London, involving a full day of interviews and presentations by members of the scientific and technical teams, followed by discussion and report writing. The FRB's official review was provided to the Lake Ellsworth team on 24 June.

\section{PI'S DRILLING FAILURE REPORT}

As part of the documentation made available to the FRB, a PI summary (including a diary of events; see Section 3) was submitted, which highlighted areas in which failures occurred, and how they might be solved. While the formal drill and programme reports, and indeed the FRB's report, cannot be reproduced here, their content is broadly in line with the abridged extracts selected below from the PI's summary, in addition to recommendations discussed in Section 6.
Drilling to Lake Ellsworth was halted as a consequence of the failure to connect the main drillhole to a subsurface cavity. The length of time taken to try to reach the cavity ( $\sim 40$ hours; 20 hours to reach the cavity depth and 20 hours to try and connect to it), in addition to previous delays due to difficulties with the drill system, meant that as a consequence of unplanned fuel consumption, insufficient fuel was available to complete the hole even if the cavity link was subsequently achieved. Further, the umbilical became frozen into the ice sheet, making it impossible for the borehole pump (which worked well throughout) to recover water from the subsurface reservoir, and thus continue deep drilling. These explanations are summarized in Table 1, alongside their potential mitigation/removal. Three options are then offered (which are non-mutually exclusive) on how to reconfigure the drilling equipment and operation in order to successfully access the lake. Other areas of the experiment requiring attention to reduce risk at a second attempt but which did not cause the drilling failure are also provided.

Option 1 involves repairing the existing equipment and repeating the same experiment. The changes outlined in Table 2 would allow the Lake Ellsworth experiment to be undertaken with considerably reduced risk of repeat failure. This is done by concentrating on solutions to the problems outlined in the assessment of drilling failure (Table 1). This option represents a way in which the drilling may restart with only moderate modifications to the equipment, and no modification to the experiment itself. In summary, it will require:

Repairs/replacements to some of the equipment (sensor system, boiler, umbilical hose and reeler, main hose reeler);

Detailed calculations of the drilling process, which are not allowed to change subsequently;

Additional expertise and spares on site (in total, $4 \times$ drill engineers, $1 \times$ lead drill engineer, $1 \times$ boiler engineer, $1 \times$ electrical engineer).

Option 2 involves two additional modifications to the Lake Ellsworth experiment, highlighted in Table 3, to further reduce the risk of failure. Both relate to 'systems tests' of equipment prior to the main field experiment. Both would be challenging and potentially costly in time and resources.

Option 3 is to rethink the experimental design. Whereas options 1 and 2 allow the Lake Ellsworth exploration programme to restart with a reduced risk of failure under the same experimental design, it is worth considering modifying the experiment to further reduce the risk.

Prior to efforts to redesign elements of the Lake Ellsworth drill system and plan a return field campaign, the items detailed in Table 4 comprise essential field logistics and repairs that are also needed. It should be noted that such repairs are essential regardless of which of the options listed in the previous section are adopted.

\section{FRB RECOMMENDATIONS FOR PROGRAMME DESIGN AND TECHNOLOGY}

After considering the PI summary and recommendations, and formal reports from the Lake Ellsworth Consortium, and after discussions following presentations to the FRB, a 45-point list of recommendations was provided to the programme as an independent assessment of the problems 
Table 1. Summary of items responsible for drilling failure and their solutions

\begin{tabular}{llll}
\hline Incident $\quad$ Failed items & Significance & Proposed resolution
\end{tabular}

Failure to link the Reeler load cells not working.
main hose to the cavity

Reeler pay-out rate not controlled satisfactorily.

Drilling information not available in required location, due to parts failure and electrical interference.

Drilling calculations on the shape of the cavity incorrect.

Insufficient fuel to continue operations

Fuel consumption different in the field compared with planned usage.

Delays and poor burner efficiency and therefore additional fuel use, due to boiler problems.

Umbilical hose freezing-in

Failure to understand the significance of water with very low temperature being returned by the umbilical pump, and apparent initial balance between the main-hose water use and water returned by the umbilical pump.
Unable to know precisely when the hose was bottoming out in the hole, resulting in bent drill head and tilt/loss of plumb line and hence likely off-vertical hole created. [By providing information to the driller to ensure the hose does not bottom out in the hole, and therefore that it hangs as a plumb line, the load cells allow gravity-controlled (vertical) drilling]

Unable to lower the drill head at required speed. Control of hole diameter and bottoming-out poor (see above). [Controlling the pay-out allows the driller to ensure the drill head is above the hole floor]

The drilling was essentially undertaken 'blindly' as specific information on drill speeds and load information was absent, and borehole temperatures and water levels were not available as needed. Control of hole diameter and bottoming-out poor (see above).

A 'bulbous'/teardrop, cavity shape was envisaged to have been built. If it was thinner than calculated by the drill consultant, this may have contributed (or led) to failure to link the main hose. Whereas sufficient fuel was purchased to drill 2 holes, last-minute changes to the drilling meant that fuel contingency was less than planned originally.

Fuel contingency was used, keeping the boiler and camp 'ticking over' while technicalities were resolved. Several

boiler issues were encountered, and while

by the end of the fieldwork it was working at the level required, its reliability is questionable given these issues.

Cold water from the main hose was probably overtopping within the firn, and wicking down the umbilical hose, thus freezing it in.
Failure analysis.

Redesign/replacement load cells.

Engineering solution required, and testing in comparable environment.

Redesign and fully test the sensor system with full drill system or analogue in a comparable

environment, to ensure reliability.

Electrical engineer needed on site, to assist with on-site sensor operation.

Revise calculations (numerical modelling) of how the water cavity forms in deep ice.

Form a firm plan for drilling operations based on best available models/data prior to purchase of fuel.

Analysis, redesign/servicing and testing of the boiler in comparable environment is needed. Boiler engineer needed on site, to resolve boiler issues as soon as possible, and to ensure it is working as needed by the drillers.

Improved models and training for drilling procedure need to be widely communicated to personnel on site. Senior hot-water driller needed on site, to oversee drilling. Additional drillers needed to share the load, especially when on 24 hour operations. encountered in the field season, and how these can be mitigated in future work.

The report also commended several aspects of the programme, including the CEE, the design and delivery of the hot-water drill system, the probe design and deployment system, cleanliness protocols, logistics management, the formal risk assessment, the programme's media and public relations work, the project management and the fact that important lessons that could be learned by the programme were now available.

The FRB's 45 recommendations covered the following eight areas: linking the main borehole to the subsurface cavity; fuel availability; umbilical hose freezing; borehole cavity modelling; management and staffing; drill safety systems; hot-water drill subsystems; and risk assessment. The most important of these recommendations - the critical issues that if solved would result in a successful mission are provided below.
In relation to linking the main borehole to the subsurface water cavity, the FRB made the following recommendations:

Reassurance of the strength of a $300 \mathrm{~m}$ dry hole was needed through mechanical modelling of the ice.

A more rigorous method involving thermal fluid dynamics modelling of the cavity formation, and the use of keyhole techniques to build the cavity, should be used to add confidence in its likely dimensions. Field data from the 2012/13 season should be used to understand the dimensions of the cavity that was built, which could help to explain why it was not linked by the main borehole.

Verticality of the boreholes should be assured if subsurface cavity linkage is to occur, and techniques that would add confidence to demonstrating this in the field should be investigated. 
Table 2. How to repair the existing equipment to allow a second drilling attempt

\begin{tabular}{lrl}
\hline Problem & Proposed solution & Consequence \\
Difficulty: \\
1 easy- \\
5 difficult
\end{tabular}

Reeler load cells

Reeler pay-out rate not controlled satisfactorily

Drilling information not available in required location

Ensuring sufficient fuel on site to complete $2 \times$ holes Ensuring boiler performance

Cold water from the main hose overtopping within the firn, and wicking down the umbilical hose

Umbilical hose replacement
Replace and test load cells, and ensure that appropriate expertise is on site for installation. Specification of load cells to be recalculated to ensure sensitivity at the level required.

Reelers need to have automated speed control and new gear ratio(s) added then tested. A possible solution is to swap the motors from hydraulic to electric.

Redesign and fully test the sensor system with full drill system or analogue in a comparable environment, to ensure reliability. Electrical engineer needed on site, to assist with on-site sensor operation.

Form a firm plan for drilling operations based on best available models/data, and do not change it subsequently.

Analysis, redesign/servicing and testing of the boiler in comparable environment is needed. Have necessary spares and expertise (boiler engineer) on site.

Improved models and training for drilling procedure need to be widely communicated to personnel on site. Senior hot-water driller needed on site, to oversee drilling. Additional drillers (4 in total, in addition to senior driller) needed to share the load, especially when on 24 hour operations. A new umbilical hose is needed. In the replacement, a borehole pump capable of working with water temperatures $>40^{\circ} \mathrm{C}$ is necessary.
Drillers would know when the drill starts to 'bottom out' in the drillhole; avoiding this ensures the hole remains vertical.

Drillers can control the descent of the drill head more accurately, thus ensuring the hole is drilled vertically.

Drillers have full information readily available, which, in conjunction with the above changes, adds confidence in the ability to drill a vertical hole. If both the umbilical and main drillholes are drilled vertically, the risk of not linking the main drillhole to the cavity is reduced.

Appropriate fuel is purchased and used, ensuring contingency and allowing proper fuel budgets to be calculated on site. Starting the drilling itself only when the boiler is working fully.

Drilling operations are fully monitored and problems predicted before they become serious.

Ensures drilling the cavity is possible, and with 2 hotter water will also contribute to ensuring verticality of the hole.
Various hardware issues encountered in the field require remedies that prevent reoccurrence. These involve (1) the load cells, which are essential for ensuring verticality of the borehole, (2) reeler speed resolution, which needs to be controlled precisely at low levels, (3) drill-nozzle extensions, which need to be more robust and fit for purpose, (4) sensor noise issues, both in terms of spare parts being available in the field and the reduction in electrical noise, (5) efficiency and safety in surface water generation, which should include a mechanical front-end loader for shovelling snow, (6) better definition and clarity in the drilling strategy, and (7) testing the hose to quantify elongation when filled with hot water and stretched.
Concerning the lack of fuel available on site, the FRB recommended that fuel contingency should be increased by bringing more fuel on site and by improving system fuel efficiencies by increasing the hot-water system's thermal capacity, adding heat recovery to the generators and adapting a rigorous fuel log to track consumption. It also recommended that increased drilling speeds would assist fuel use, and this could be achieved by replacing the standard cavity pump motor with a high-temperature motor that has fewer restrictions of use during cavity drilling and reaming; reassessing the optimal length of the drill nozzle; and using a forward-only spray configuration when building the hole.

Table 3. System tests that would help reduce risk of failure

\begin{tabular}{|c|c|c|c|}
\hline Problem & Proposed solution & Consequence & $\begin{array}{c}\text { Difficulty: } \\
1 \text { easy- } \\
5 \text { difficult }\end{array}$ \\
\hline
\end{tabular}

Reducing operational risk in drilling

Reducing operational risk in probe/corer deployment
Full system test of drill equipment, preferably in a polar environment.

Undertake deep-sea trials or rigorous analogue tests* of probe and corers.
Drillers gain experience of the full system, and problem-solve issues prior to main experiment. Ensure the instruments work as integrated units within appropriate conditions. Equipment would need to be re-cleaned and bagged afterwards, but this is needed in any case prior to a second attempt.

*This could be done in a large temperature-controlled pressure vessel and with a temperature-controlled shipping container. This has advantages over sea trials (e.g. easy repetition, repair, cost per test) but has a capital cost. 
Table 4. Essential repairs to equipment

\begin{tabular}{l} 
Item \\
\hline Boiler $\quad \begin{array}{c}\text { A full service of the boiler is required, with } \\
\text { special attention being paid to known issues } \\
\text { (e.g. pressurization sensors, pressurization pumps, } \\
\text { valves, heat trace, and control boards). }\end{array}$
\end{tabular}

Umbilical

reeler and hose

Main reeler and hose

Drill head extensions which would cause unacceptable delays on
A new umbilical hose and pump is required. Ideally, the pump needs to be capable of working at temperatures $>40^{\circ} \mathrm{C}$ (preferably $\sim 90^{\circ} \mathrm{C}$ ). The winch system needs to be modified to cope with precise slow pay-out at low temperatures. Load-cell and pay-out information needs to be guaranteed at the driller's position.

The winch system needs to be modified to cope with precise slow pay-out at low temperatures. Potentially a new hose may be needed, depending on how it has survived with ice inside. Load-cell and pay-out information needs to be guaranteed at the driller's position. The main-drill reeler scrolling gear needs to be re-engineered/adjusted - it required manual intervention in 2012/13, withdrawing $>3 \mathrm{~km}$.

Drill-head extensions bent on deployment, due to bottoming-out in the main hole. While event can be mitigated by redesign of load cells and pay-outs, it can also be aided potentially by redesign of the head and/or choosing a different material from brass, possibly titanium, which is stronger.

Logistics needed

Result

Maintenance on the boiler is best undertaken in the UK, by the manufacturer. The umbilical container needs and sent back to the UK.
A fully serviced boiler, upgraded to cope with wintering and fully assessed with respect to its capability and suitability for drilling a deep borehole in Antarctica.

An umbilical hose/drill capable of drilling a vertical hole and creating a cavity, with low risk of failure.
The main hose currently has water (ice) within it. This needs to be heated and blown through. The condition of the hose then needs to be assessed. The main drill container needs to be removed from Antarctica and sent back to the UK. Re-engineering/adjustment of scroll gear and testing (possible in UK and elsewhere).

Model drill-head design options, investigate the use of titanium/other materials for drill-head extensions.
A main hose/drill capable of drilling a vertical hole and creating a cavity that can be withdrawn rapidly with low risk of failure.

Drill-head designs that are not so easily bent as those used previously.
In terms of the freezing-in of the umbilical hose, the FRB agreed with the engineer's assessment that it was caused by wicking of water from the main borehole down the umbilical, where it froze midway between the surface and the cavity. Though not mentioned in the FRB's report, this was a single point of failure, regardless of whether the cavity was linked, as without being able to free the umbilical the submersible pump would have been unable to access the water created beneath. Hence, avoiding this reoccurring is essential to future success. The FRB made recommendations that would reduce the risks. These included the following:

Explore alternative procedures for creating and confirming the main link between the main borehole and cavity. These included using the umbilical hose to drill the main borehole to $300 \mathrm{~m}$, keeping it dry once below $70 \mathrm{~m}$ from the ice surface; and developing a small cavity at $70 \mathrm{~m}$, to soak up excess from the main borehole.

Keep the umbilical moving while the main borehole is being built to avoid sticking.

Other recommendations focused on keeping the experiment running if the umbilical hose became stuck. These included aiming to create a cavity shape that is shallow and wide, by adjusting the nozzle spray direction once at the ice depth required, as it would allow the bulk of subsurface water to be accessed by the pump, even if it were frozen stuck; and determining a back-up plan for when the umbilical hose becomes stuck.

On the matter of borehole and cavity modelling, the FRB recommended using a new approach to characterization of the cavity shape, and that this should be discussed by other glaciologists and drillers. Use of dynamic thermal modelling was suggested, in which melting efficiency and freeze rates are model outputs rather than inputs based on experience/empirical data. Once this modelling has been undertaken, the drilling strategy should be rewritten, to include a set of tools (i.e. calculations, charts, tables) that would be used to guide the field team responsible for implementing the strategy.

Concerning staffing and expertise, the FRB agreed with the programme's self-assessment, that additional personnel were needed on site. Specific recommendations included the following:

External drilling experts should be engaged in the redesign of the drill. An experienced senior hot-water drilling engineer should also be involved in both drill development and deployed into the field.

An external drill design review should be configured, to offer advice on design and to verify implementation. A formal readiness review should also be commissioned before deployment to the field.

Sufficient expertise is needed in the field, including a senior hot-water driller and three drillers per shift. Additional expertise to cover electronics, generators and boilers is also necessary.

A number of recommendations were provided concerning safety systems, especially the deployment of emergency stop buttons and cords in strategic locations around the field site, the installation of load circuit interrupters on all heat trace elements, and integral temperature/flow safety limits within the boiler. 
Concerning the hot-water drill subsystems, the FRB's report included these recommendations:

Use of a single boiler represents a potential single point of failure. Multiple boilers should be considered to reduce this risk, albeit with an appreciation that more maintenance may be needed.

Given the reelers were difficult to control, converting their drives from hydraulic to electrical could solve many of the issues reported from the field.

Non-shielded signal cables should be shielded against noise, to guarantee sensor information at the driller's location. Also, the use of wireless data transmission could be considered to further reduce electrical noise issues.

A down-hole camera should be used to confirm hole integrity and dimensions.

The FRB commended the programme's use of a formal risk assessment, and in particular the Markov chain approach used to understand risk in both the drill and probe (Brito and others, 2012a). However, the FRB noted that quantitative data for the drill were obtained by only one expert from the programme, with others in the programme offering comments. A more defendable dataset could be built by gaining input from colleagues outside the programme. Manufacturer's data were used as input to the risk model on many occasions. The FRB recommended testing components to form an independent evaluation of performance rather than relying on manufacturers' information. Finally, to ascertain whether the project has undue risk, a comparison of the quantified risks for Lake Ellsworth should be compared with those (presently unquantified) for the successful WISSARD (Whillans Ice Stream Subglacial Access Research Drilling) and IceCube (South Pole) drills.

\section{LAKE ELLSWORTH DRILL REPORT}

The bulk of the critical recommendations made by the FRB concerned the hot-water drill and related systems. Because of this, engineers at BAS, responsible for the design, development and deployment of the drill system, compiled a formal report on the modifications needed on the drill in response to the FRB recommendations. A draft response was presented to the 7 th International Workshop on Ice Drilling Technology (Hill and Lake Ellsworth Consortium, 2013), and feedback from this meeting was used to clarify a number of points in the final report, which was led by David Blake at BAS. In addition, commercial drilling experts were invited to a meeting held at BAS on 9 October 2013, to discuss existing technical solutions to various drilling problems, and to ascertain the feasibility of importing them to use in Antarctic hot-water drilling. Again, feedback from this meeting was used in the BAS-led drill report.

The drill report proposed resolutions to issues highlighted by the FRB in terms of faults being either primary (initiating a problem) or secondary (deriving from, and adding to, a problem). An example of a primary fault is the faulty load cells, which meant drill-head bottoming in the drillhole could not be identified. This issue led to bending of the drill extension nozzle, which itself is thus a secondary fault. The report also responded to all the recommendations of the FRB, the vast majority of which were accepted.
Of the issues that were not accepted (yet), the use of hydraulics to run the reelers was questioned as an effective hydraulic system. In fact such a system was used effectively in the field for the Lake Ellsworth probe deployment system. This power unit was able to provide lowering speeds down to $\mathrm{mm} \mathrm{s}^{-1}$, which is well within the range required by the hot-water drill. Such a system could be used to drive the hose reelers. This is not to say that an electrical system will not be considered further, but the use of hydraulics should not be ruled out at this stage.

A second issue that required resolving following FRB concerns related to the mechanical strength of a dry borehole down to $300 \mathrm{~m}$ depth, the issue being that it may close due to creep of ice during the experiment. This is not considered to be a significant problem, however, as the work of Gow (1963) on the $309 \mathrm{~m}$ deep Byrd ice-cored hole demonstrated closure of only $20 \mathrm{~mm}$ over 12 months. Hence, the mechanical integrity of a dry borehole at $300 \mathrm{~m}$ is likely to be sufficient for the short-term ( $<10$ days) purposes required at Lake Ellsworth.

A third point concerned adding confidence to knowing hole verticality. A simple dead-reckoning system is used at South Pole to demonstrate sufficient 'hole verticality', using motion sensors (tiltmeters and a compass) at the drill head. At Lake Ellsworth, a similar system could either be deployed as drilling takes place, or subsequently to measure the hole prior to probe deployment as a discrete operation.

Fourth, the recommendation concerning investigating how to free a frozen hose was not accepted. Once frozen, it is already too late to get hoses out. Instead, the recommendation that the hoses be continually monitored for their state of health in the borehole was accepted as the best means to avoid freezing the hose within the ice sheet.

Fifth, the FRB recommended investigating alternative procedures for creating and confirming the link between the cavity and main hose. While this was accepted, it is not yet clear exactly which of several alternative drilling procedures is most preferable. For example, the actual need to link the cavity and main borehole is the most important issue at this stage. It may well be that a procedure that does not require such a link can be designed, involving two separate holes (one for water creation and storage and one for the main hole), although its own separate risks must then be considered. Further discussion is ongoing, but the point that the drilling procedure should be modified to lower the risk of drilling failure is well made.

\section{PATHWAY FOR THE LAKE ELLSWORTH PROGRAMME}

While the various reports and responses, discussed above, demonstrate that considerable development of the hot-water drill is needed to ensure the future successful exploration of Lake Ellsworth, they also show that the problems encountered are tractable. While considerable effort is needed to upgrade and test the drill to a satisfactory level, the reports provide confidence that the mission remains feasible. The main issue relates to ensuring the subsurface cavity link to the main borehole. Either a failsafe procedure needs to be developed, which should involve borehole verticality assurance and knowledge of the size, shape and location of the cavity, or this element of the drilling should be eliminated. By not needing to link a subsurface cavity, a single point of failure would be removed. In doing so, other 
risks may be introduced, however. In the absence of a cavity link, engineering solutions are needed on the creation and storage of sufficient water for deep-ice drilling; the pumping of water within the main borehole from below the permeable firn layer to avoid water loss; and the extraction of $\sim 300 \mathrm{~m}$ of borehole fluid prior to lake entry to avoid borehole fluid entering the lake. In this situation, it is likely that a borehole pump will need to be deployed in the same hole as the main hose, which would potentially lead to tangling of the hoses. Also, without a linked cavity, it may be difficult to ensure circulation of all the subsurface water, which could lead to reduced water temperature in key places and freezing of the borehole.

The issue of whether or not to attempt a subsurface cavity link during a second attempt to explore the lake is clearly central to determining the future pathway for the programme. An engineering assessment is required, in order to establish feasibility of the options available and, from this, a preferred approach. It is clear to programme members that a second attempt to explore the lake cannot take place until a reliable deep-ice drill has been developed. This is an engineering, rather than a scientific, issue and may require several years of work. Hence, the next step for the programme is to concentrate on developing and testing a deep-ice drill before a return mission to the lake can be proposed. The scientific hypotheses relating to subglacial lake exploration remain compelling, and Lake Ellsworth remains an ideal target to test them.

\section{SUMMARY AND CONCLUSIONS}

Despite having been planned for $>10$ years, attempts to access Subglacial Lake Ellsworth $3 \mathrm{~km}$ beneath the surface of the West Antarctic ice sheet using a bespoke hot-water drilling system were unsuccessful in December 2012. The main reason for the failure relates to a subsurface cavity of water $300 \mathrm{~m}$ beneath the ice surface that could not be connected to by the main drillhole, and which consequently resulted in insufficient water available to continue drilling deeper. To explain why the connection was not made, it is highly likely that one or both drillholes were drilled nonvertically, leading to an enhanced offset at $300 \mathrm{~m}$. Evidence for this comes from drill-nozzle extensions, which were bent as a consequence of grounding the drill head on the base of the hole. This situation was caused by a series of equipment problems, including load-cell failures on both hose reelers (which would have instructed when drill 'bottoming' was occurring), reeler pay-out rates being difficult to control, and a lack of information readily available to the drillers. The situation was made worse by the initial poor performance of the boiler, which meant drilling speeds could not be as high as planned, and eventually a lack of fuel to continue. Further, but separate from equipment issues, the experiment design in which two drillholes were separated by only $2 \mathrm{~m}$ led to exchange of water between them at the base of the firn layer (at $\sim 60 \mathrm{~m}$ depth), which caused wicking of cold water down the cavity drillhole and the eventual freezing-in of the hose within it.

On return to the UK, the Lake Ellsworth team undertook a self-evaluation of the drilling failure, which was fed into an independent review of the programme, which in turn made its own conclusions on why the drilling did not work as planned and offered recommendations on how the problems may be mitigated. These recommendations were then assessed by the Lake Ellsworth team, to form conclusions on the drilling failure and form a pathway by which the experiment can be redesigned and restarted.

The likely time frame over which the modifications to the drilling equipment and procedure may be completed, and then implemented in a second attempt to explore Lake Ellsworth, is on the order of 5 years. In 2014, it is hoped that all the drilling equipment will be returned to the UK. Then, pending additional funding, work can begin on re-engineering the drill in line with FRB recommendations. This will likely take another year, and with the necessity for thorough field testing (and subsequent changes) over a further 24 month period, the earliest equipment could be installed back to the lake would be the 2018/19 season.

Despite the obvious setback that the Lake Ellsworth programme has experienced, the lessons learnt from the first attempt to undertake clean direct measurement and sampling of this pristine environment have been well defined. These problems are tractable, and if their solutions can be implemented it is highly likely that the next opportunity for exploration will be more successful. Looking ahead, if we are to directly explore the vast sub-ice continent of Antarctica, clean, efficient and rapid access to the subglacial environment is a necessity. Consequently, the satisfactory redesign of the Lake Ellsworth hot-water drill will be of value not only for the exploration of this lake, but to a broad range of future Antarctic exploratory research in the decades ahead.

\section{ACKNOWLEDGEMENTS}

The Subglacial Lake Ellsworth Consortium, supported by Natural Environment Research Council (NERC) grant NE/ G00465X/1, is a multidisciplinary group of science, engineering and support teams from the British Antarctic Survey (BAS), the UK National Oceanography Centre (NOC), Imperial College London and the Universities of Edinburgh, Bristol, Durham, Aberdeen and Newcastle (among others). Thanks are extended to the members of the 2012 field party (Chris Hill, Andy Tait, Andy Webb, Ed Waugh, Robin Brown, Riet van de Velde, Scott Iremonger, Martyn Tranter, Dominic Hodgson and David Pearce) and to participants in the wider Lake Ellsworth Consortium, in particular at BAS and NOC. Thanks are also given to members of the Failure Review Board (Frank Rack (Chair), Uwe Nixdorf, David Meldrum, Jin Wang and Terry Benson) for constructive criticisms and insights into deep-ice drilling, and to staff at NERC for implementing the formal review.

\section{REFERENCES}

Bentley C (1996) Water kept liquid by warmth from within. Nature, 381(6584), 645 (doi: 10.1038/381645a0)

Bentley MJ, Christoffersen P, Hodgson DA, Smith AM, Tulaczyk S and Le Brocq AM (2011) Subglacial lake sediments and sedimentary processes: potential archives of ice sheet evolution, past environmental change, and the presence of life. In Siegert MJ, Kennicutt $\mathrm{MCl}$ and Bindschadler RA eds. Antarctic subglacial aquatic environments. (Geophysical Monograph Series 192) American Geophysical Union, Washington, DC, 83-110

Brito MP, Griffiths G and Mowlem M (2012a) Exploring Antarctic subglacial lakes with scientific probes: a formal probabilistic approach for operational risk management. J. Glaciol., 58(212), 1085-1097 (doi: 10.3189/2012JoG12J007) 
Brito MP, Makinson K, Tait A, Hill C and Griffiths G (2012b) Reliability Case Notes No. 7. Risk assessment of the hot-water drilling system for accessing subglacial Lake Ellsworth. (NOC Res. Consult. Rep. 28) National Oceanography Centre, Southampton

Brito MP, Griffiths G, Mowlem M and Makinson K (2013) Estimating and managing blowout risk during access to subglacial Antarctic lakes. Antarct. Sci., 25(1), 107-118 (doi: 10.1017/S0954102012000442)

Drewry DJ and Meldrum DT (1978) Antarctic airborne radio echo sounding, 1977-78. Polar Rec., 19(120), 267-273 (doi: 10.1017/S0032247400018271)

Ellis-Evans JC and Wynn-Williams D (1996) A great lake under the ice. Nature, 381(6584), 644-646 (doi: 10.1038/381644a0)

Fricker HA, Scambos T, Bindschadler R and Padman L (2007) An active subglacial water system in West Antarctica mapped from space. Science, 315(5818), 1544-1548 (doi: 10.1126/ science.1136897)

Fricker HA and 13 others (2011) Siple Coast subglacial aquatic environments: the Whillans Ice Stream Subglacial Access Research Drilling Project. In Siegert MJ, Kennicutt $\mathrm{MCl}$ and Bindschadler RA eds. Antarctic subglacial aquatic environments. (Geophysical Monograph Series 192) American Geophysical Union, Washington, DC, 199-220

Gow AJ (1963) Results of measurements in the 309 meter bore hole at Byrd Station, Antarctica. J. Glaciol., 4(36), 771-784

Hill C and Lake Ellsworth Consortium (2013) A review of the subglacial Lake Ellsworth 2012/13 field campaign. In Abstracts from 7 th International Workshop on Ice Drilling Technology, 9-13 September 2013, Madison, WI, USA, 23 http://icedrill.org/ 7th-international-workshop-on-ice-drilling-technology/7-ws-idt_abstract-book_FINAL.pdf

Kapitsa AP, Ridley JK, Robin GdeQ, Siegert MJ and Zotikov I (1996) A large deep freshwater lake beneath the ice of central East Antarctica. Nature, 381(6584), 684-686 (doi: 10.1038/381684a0)

Lukin V and Bulat S (2011) Vostok subglacial lake: details of Russian plans/activities for drilling and sampling. In Siegert MJ, Kennicutt MC II and Bindschadler RA eds. Antarctic subglacial aquatic environments. (Geophysical Monograph Series 192) American Geophysical Union, Washington, DC, 187-197

National Research Council (NRC). Committee on Principles of Environmental Stewardship for the Exploration and Study of Subglacial Environments (2007) Exploration of Antarctic subglacial aquatic environments: environmental and scientific stewardship. National Academies Press, Washington, DC

Oswald GKA and Robin GdeQ (1973) Lakes beneath the Antarctic ice sheet. Nature, 245(5423), 251-254 (doi: 10.1038/245251a0)

Priscu JC and 9 others (2003) An international plan for Antarctic subglacial lake exploration. Polar Geogr., 3927(1), 69-83

Ridley JK, Cudlip W and Laxon SW (1993) Identification of subglacial lakes using ERS-1 radar altimeter. J. Glaciol., 39(133), 625-634
Robin GdeQ (1969) Interpretation of radio echo sounding in polar ice sheets. Philos. Trans. R. Soc. London, 265(1166), 437-505 (doi: 10.1098/rsta.1969.0063)

Robin GdeQ, Drewry DJ and Meldrum DT (1977) International studies of ice sheet and bedrock. Philos. Trans. R. Soc., Ser. B, 279(963), 185-196

Ross N and 26 others (2011a) Ellsworth Subglacial Lake, West Antarctica: a review of its history and recent field campaigns. In Siegert MJ, Kennicutt MC II and Bindschadler RA eds. Antarctic subglacial aquatic environments. (Geophysical Monograph Series 192) American Geophysical Union, Washington, DC, $221-234$

Ross $\mathrm{N}$ and 8 others (2011b) Holocene stability of the AmundsenWeddell ice divide, West Antarctica. Geology, 39(10), 935-938 (doi: 10.1130/G31920.1)

Ross N and 8 others (2014) The Ellsworth Subglacial Highlands: inception and retreat of the West Antarctic Ice Sheet. Geol. Soc. Am. Bull., 126(1-2), 3-15 (doi: 10.1130/B30794.1)

Siegert MJ (2002) Which are the most suitable Antarctic subglacial lakes for exploration? Polar Geogr., 26(2), 134-146 (doi: 10.1080/789610135)

Siegert MJ, Dowdeswell JA, Gorman MR and McIntyre NF (1996) An inventory of Antarctic sub-glacial lakes. Antarct. Sci., 8(3), 281-286 (doi: /10.1017/S0954102096000405)

Siegert MJ and 7 others (2004) Subglacial Lake Ellsworth: a candidate for in situ exploration in West Antarctica. Geophys. Res. Lett., 31(23), L23403 (doi: 10.1029/2004GL021477)

Siegert MJ, Carter S, Tabacco I, Popov S and Blankenship DD (2005) A revised inventory of Antarctic subglacial lakes. Antarct. Sci., 17(3), 453-460 (doi: 10.1017/S0954102005002889)

Siegert MJ, Popov S and Studinger M (2011) Vostok subglacial lake: a review of geophysical data regarding its discovery and topographic setting. In Siegert MJ, Kennicutt MC II and Bindschadler RA eds. Antarctic subglacial aquatic environments. (Geophysical Monograph Series 192) American Geophysical Union, Washington, DC, 45-60

Siegert MJ and 16 others (2012) Clean access, measurement, and sampling of Ellsworth Subglacial Lake: a method for exploring deep Antarctic subglacial lake environments. Rev. Geophys., 50(RG1), RG1003 (doi: 10.1029/2011RG000361)

Wingham DJ, Siegert MJ, Shepherd A and Muir AS (2006) Rapid discharge connects Antarctic subglacial lakes. Nature, 440(7087), 1033-1036 (doi: 10.1038/nature04660)

Woodward J and 9 others (2010) Location for direct access to subglacial Lake Ellsworth: an assessment of geophysical data and modeling. Geophys. Res. Lett., 37(11), L11501 (doi: 10.1029/2010GL042884)

Wright A and Siegert M (2012) A fourth inventory of Antarctic subglacial lakes. Antarct. Sci., 24(6), 659-664 (doi: 10.1017/ S095410201200048X) 